Jurnal Kesehatan Masyarakat

\title{
PENGETAHUAN, DETEKSI DINI DAN VAKSINASI HPV SEBAGAI FAKTOR PENCEGAH KANKER SERVIKS DI KABUPATEN SUKOHARJO
}

\author{
Yuli Kusumawati ${ }^{1 凶}$, Ridhiya Wiyasa $\mathrm{N}^{2}$, Eka Nurul Rahmawati ${ }^{3}$ \\ 1,2,3Prodi Kesehatan Masyarakat Fakultas Ilmu Kesehatan Universitas Muhammadiyah Surakarta
}

\begin{abstract}
Abstrak
Data di rumah sakit Kabupaten Sukoharjo, mulai tahun 2011 sampai 2013 selalu terdapat kejadian kanker serviks meskipun jumlahnya berfluktuatif. Penelitian ini bertujuan untuk mengetahui hubungan antara pengetahuan, deteksi dini papsmear, dan vaksinasi HPV dengan kejadian kanker serviks. Penelitian ini merupakan penelitian observasional dengan rancangan case control study. Populasi adalah seluruh pasien wanita yang tercatat di bangsal VK RSUD Sukoharjo sejak bulan Januari 2012 sampai bulan September 2013 yaitu sebanyak 759 orang. Analisis data menggunakan uji chy square dan Fisher Exact. Hasil penelitian menunjukkan bahwa terdapat hubungan antara perilaku deteksi dini pap smear dengan kejadian kanker serviks, tidak ada hubungan antara pengetahuan dengan kejadian kanker serviks, serta tidak ada hubungan antara vaksinasi HPV dengan kejadian kanker serviks. Perilaku deteksi dini dengan papsmear dan vaksinasi belum terbukti sebagai faktor pencegah kanker serviks.
\end{abstract}

\section{KNOWLEDGE, EARLY DETECTION, AND HPV VACCINATION AS PREVENTION FACTORS OF CERVICAL CANCER IN SUKOHARJO DISTRICT}

\begin{abstract}
Data from Sukoharjo hospital showed that in the beginning 2011 to 2013 there is always incidence of cervical cancer although the numbers are are fluctuated. This study aimed to determine the relationship between knowledge, behavior of early detection by Pap smear, and HPV vaccination and the incidence of cervical cancer. This study was an observational study with case control study design. The population was all offemale patient who was recorded in hospital wards VK Sukoharjo since Januari 2012 until September 2013 that as many as 759 people. Analysis of data using chy square test and fisher exact. The results showed that there was a relationship between the behavior of early detection by pap smears and the incidence of cervical cancer, and in opposite there was no relationship between knowledge and HPV vaccination and the incidence of cervical cancer. The behavior of early detection by pap smear and HPV vaccination has not been proven as a deterrent factor of cervical cancer.
\end{abstract}

CC 2016 Universitas Negeri Semarang 


\section{Pendahuluan}

Saat ini, penyakit non menular yang cukup mengkhawatirkan bagi masyarakat terutama kaum wanita adalah kanker serviks. Penyakit kanker serviks menduduki peringkat pertama kematian pada wanita akibat penyakit keganasan.Perjalanan penyakit kanker yang sangat lambat, pada stadium awal prakanker sebenarnya dapat diketahui dengan melakukan deteksi dini papsmear. Human pappiloma Virus $(H P V)$ telah diketahui sebagai penyebab terjadinya kanker serviks, yang dapat ditularkan melalui hubungan seksual, infeksi beberapa jenis virus, dan personal hygiene (Yayasan Kanker Indonesia, 2011). Bustan (2007), menyatakan gejala kanker serviks mulai dapat diketahui dengan adanya keluar cairan dari jalan lahir (keputihan), contact bleeding (perdarahan sewaktu berhubungan), merasa sakit pada waktu coitus/berhubungan seksual, dan terjadi perdarahan walaupun telah memasuki masa menopouse.

Kematian akibat kanker payudara dan kanker serviks di dunia pada tahun 2010 sebanyak 247.000 kasus dan pada tahun 2011 sebanyak 273.500 kasus (WHO, 2013). Menurut Yayasan Peduli Kanker Serviks Indonesia (2011), di Indonesia setiap tahun jumlah penderita kanker serviks mencapai 15.000 kasus. Pada tahun 2030, jumlah penderita kanker serviks di Indonesia diperkirakan akan terus meningkat hingga sebesar tujuh kali lipat.

Studi yang dilakukan oleh Wijaya (2000) membuktikan bahwa wanita yang berhubungan seksual pada usia kurang dari 20 tahun mempunyai risiko terkena kanker serviks dua kali lipat dibandingkan dengan yang berhubungan seks setelah usia 20 tahun. Selain itu, terjadinya kanker serviks juga dipicu oleh kebersihan daerah kewanitaan yang kurang. Kebersihan genital yang buruk memiliki risiko terkena kanker serviks 38,965 kali dibandingkan dengan kebersihan genital yang baik (Has, 2009). Personal hygiene yang tidak baik dan penggunaan pembalut tidak berkualitas dengan kandungan bahan pemutih (dioksin) dapat menghambat sirkulasi udara pada daerah kewanitaan. Dioksin dapat menguap apabila bereaksi dengan darah menstruasi, sehingga hal ini juga dicurigai merupakan faktor risiko kanker serviks (Kartikawati,
2012). Organ kewanitaan akan menjadi lembab dan merangsang tumbuhnya berbagai bakteri patogen yang dapat menyebabkan kanker serviks apabila menggunakan pantyliner terus menerus (Wijaya, 2010).

Faktor perilaku seperti melakukan hubungan seksual pertama pada usia dini (kurang dari16 tahun), berganti-ganti pasangan seksual yang menyebabkan infeksi herpes genetalis atau infeksi klamidia menahun, pemakaian DES (dietilstilbestrol) untuk mencegah keguguran, gangguan sistem kekebalan tubuh, pemakaian pil KB jangka lama, merokok, dan kelompok ekonomi lemah juga telah diketahui sebagai faktor risiko kanker serviks (Kartikawati, 2013). Penelitian yang telah dilakukan Indrawati (2012), juga menyimpulkan hasil personal hygiene yang kurang baik, memiliki risiko terkena kanker serviks 19,386 kali dibandingkan dengan wanita yang memiliki personal hygiene yang baik. Menurut Bustan (2007), wanita dengan personal hygiene yang buruk berisiko lebih besar untuk terkena kanker serviks daripada wanita dengan personal hygiene yang baik. Personal hygiene yang buruk meliputi penggunaan pembalut dengan dioksin, penggunaan kloset umum yang kurang saniter, dan penggunaan antiseptik pada serviks (Wijaya, 2010).

Data Provinsi Jawa Tengah menunjukkan kejadian seluruh kanker pada tahun 2009 sebanyak 24.204 kasus. Kejadian ini mengalami penurunan 12,07\% dibandingkan tahun 2008 sebanyak 27.125 kasus, dengan kanker serviks sebanyak 9.113 kasus $(\mathrm{PR}=0,028 \%)$ (Dinkes Jateng, 2009). Kabupaten Sukoharjo sebagai salah satu daerah transisi antara kota dan desa dengan berbagai faktor risiko seperti polusi lingkungan dari industri, perilaku berisiko, dan stres akan meningkatkan risiko terjadinya peningkatkan kanker termasuk kanker serviks. Pada tahun 2012 terdapat 114 penderita kanker serviks dan tahun 2011 sebanyak 306 penderita, serta pada bulan Januari 2013 sebanyak 21 penderita. Penurunan jumlah penderita kanker serviks masih perlu ditangani secara serius karena kejadian kanker serviks salah satunya disebabkan oleh faktor mobilitas penduduk (Dinkes Sukoharjo, 2013).

Studi pendahuluan yang dilakukan di RSUD Sukoharjo diperoleh data pada tahun 
2012 terdapat 29 pasien kanker leher rahim, dan 2 diantaranya telah mengalami stadium lanjut III dengan anemia, dan pada tahun 2013 hingga Bulan April 2013 tercatat 7 wanita menderita kanker leher rahim (RSUD Sukoharjo, 2013). Karena banyaknya faktor yang berperan dalam terjadinya kanker serviks, maka seorang wanita perlu mengetahui faktorfaktor tersebut dan berupaya untuk mengurangi atau menghindarinya. Kanker serviks dapat dapat ditegakkan dengan diagnosis melalui beberapa pemeriksaan laboratorium antara lain: 1). Pemeriksaan pap smear (sitologi), yaitu pemeriksaan dengan cara pengambilan lapisan dari permukaan leher rahim atau vagina untuk menilai perubahan bentuk sel; 2). Pemeriksaan Schiller atau lebih dikenal dengan IVA, yaitu pemeriksaan dengan menggunakan larutan iodium untuk mengetahui perubahan warna jaringan yang mengalami kelainan 3).Pemeriksaan kolposkopi, yaitu pemeriksaan dengan menggunakan alat untuk menentukan adanya daerah abnormal dan letak kelainannya (Sastrosudarmono, 2011). Kelainan atau abormalitas jaringan pada serviks merupakan gejala awal kanker serviks, sehingga ketika mengalaminya dapat dilakukan upaya untuk mendeteksi dini, salah satunya dengan pemeriksaan pap smear. Pemeriksaan ini adalah salah satu metode deteksi dini kanker serviks yang dinilai cukup akurat. Namun kenyataannya belum semua masyarakat terutama wanita, memahami dan mau melakukannya dengan berbagi alasan, seperti malu, takut akan hasilnya, dan juga masalah biaya. Wanita sering tidak mengenali gejala awal dan datang untuk melakukan pemeriksaan sudah dalam stadium lanjut. Demikian juga, ketika seorang wanita sudah terdeteksi kanker serviks, kadang tidak langsung ke pelayanan kesehatan, namun ada pula yang lebih memilih ke pengobatan alternatif dengan berbagai alasan. Setelah upaya deteksi dini dengan pemeriksaan pap smear, upaya pencegahan terhadap kanker serviks dapat dilakukan dengan memberikan vaksin HPV. Menurut Rasjidi (2009), vaksinasi HPV yang diberikan kepada pasien bisa mengurangi infeksi Human Papiloma Virus, karena mempunyai kemampuan proteksi $>90 \%$. Tujuan dari vaksin propilaktik dan vaksin pencegah adalah untuk mencegah perkembangan infeksi HPV dan rangkaian dari event yang mengarah ke kanker serviks. Kebanyakan vaksin adalah berdasarkan respons humoral dengan penghasilan antibodi yang menghancurkan virus sebelum menjadi intraseluler. Vaksin propilatik HPV sangat menjanjikan, namun penerimaan seluruh populasi heterogenous dengan tahap pendidikan berbeda dan kepercayaan kultur berbeda tetap dipersoalkan.

Berdasarkan uraian tersebut, maka perlu dilakukan penelitaan tentang pengetahuan kanker serviks, upaya deteksi dini, dan vaksin HPV dengan kejadian kanker serviks di Kabupaten Sukoharjo. Penelitian ini bertujuan untuk mengetahui hubungan antara pengetahuan, deteksi dini papsmear, dan vaksinasi HPV dengan kejadian kanker serviks

\section{Metode}

Penelitian ini merupakan penelitian observasional dengan rancangan case control study. Populasi adalah seluruh pasien wanita yang tercatat di bangsal VK RSUD Sukoharjo sampai bulan September 2013 yaitu sebanyak 759 orang. Sampel kasus diambil secara total dari kasus penderita kanker serviks di RSUD Kabupaten Sukoharjo hingga bulan September 2013 sebanyak 32 orang, sedangkan sampel kontrol diambil dengan jumlah yang sama secara simple random sampling dari pasien obgyn yang bukan penderita kanker serviks, yaitu pasien partus normal yang berada di ruang perawatan Bougenville RSUD Kabupaten Sukoharjo. Analisis data menggunakan uji chy square dan Fisher exact dan estimasi nilai OR dengan bantuan program SPSS di laboratorium komputer Fakultas Ilmu Kesehatan Universitas Muhammadiyah Surakarta.

\section{Hasil dan Pembahasan}

Hasil penelitian menunjukkan bahwa karekteristik umur penderita kanker serviks (kasus) dan bukan penderita kanker serviks (kontrol) hampir sama. Rata-rata umur pada kasus 50,72 tahun dengan SD 8,9 tahun, sedangkan pada kontrol sedikit lebih tinggi yaitu 51, 56 tahun dengan SD 9,47 tahun. Umur termuda pada kasus 31 tahun dan kontrol 30 tahun, umur tertua pada penderita kanker serviks 70 tahun dan kontrol 31 tahun. 
Tabel 1. Karakteristik Responden berdasarkan Tingkat Pendidikan dan Pekerjaan di RSUD Sukoharjo

\begin{tabular}{|c|c|c|c|c|c|c|}
\hline $\begin{array}{r}\text { Variabel } \\
\text { Tk.Pendidikan }\end{array}$ & \multicolumn{2}{|c|}{$\begin{array}{c}\text { Penderita Kanker Serviks } \\
\text { (Kasus) } \\
\mathbf{n}(\%) \\
\end{array}$} & \multicolumn{2}{|c|}{$\begin{array}{l}\text { Bukan Penderita Kanker } \\
\text { Serviks (Kontrol) n }(\%)\end{array}$} & \multicolumn{2}{|c|}{ Jumlah } \\
\hline Tidak Sekolah & 6 & $(18,8)$ & 5 & $(15,6)$ & 11 & $(17,2)$ \\
\hline $\mathrm{SD}$ & 22 & $(68,8)$ & 20 & $(62,5)$ & 42 & $(65,6)$ \\
\hline SMP & 3 & $(9,4)$ & 6 & $(18,8)$ & 9 & $(14,9)$ \\
\hline SMA & 1 & $(3,1)$ & 1 & $(3,1)$ & 2 & $(3,1)$ \\
\hline PT & 0 & $(0,0)$ & 0 & $(0,0)$ & 0 & $(0,0)$ \\
\hline Jumlah & 32 & (100) & 32 & $(100)$ & 64 & (100) \\
\hline \multicolumn{7}{|l|}{ Pekerjaan } \\
\hline IRT & 11 & $(34,4)$ & 14 & $(43,8)$ & 25 & $(39,1)$ \\
\hline Swasta & 9 & $(28,1)$ & 9 & $(28,1)$ & 19 & $(28,1)$ \\
\hline Wiraswasta & 3 & $(9,4)$ & 5 & $(15,6)$ & 8 & $(12,5)$ \\
\hline Pegawai & 1 & $(3,1)$ & 2 & $(6,3)$ & 3 & $(4,7)$ \\
\hline Petani & 3 & $(9,4)$ & 2 & $(6,3)$ & 5 & $(7,8)$ \\
\hline Buruh & 5 & $(15,6)$ & 0 & $(0)$, & 5 & $(7,8)$ \\
\hline Jumlah & 32 & $(100)$ & 32 & (100) & 64 & (100) \\
\hline
\end{tabular}

Sumber Data : Data Primer

Tabel 2. Gambaran tentang Pengetahuan dan Deteksi Dini Kanker Serviks Kasus dan Kontrol di RSUD Sukoharjo

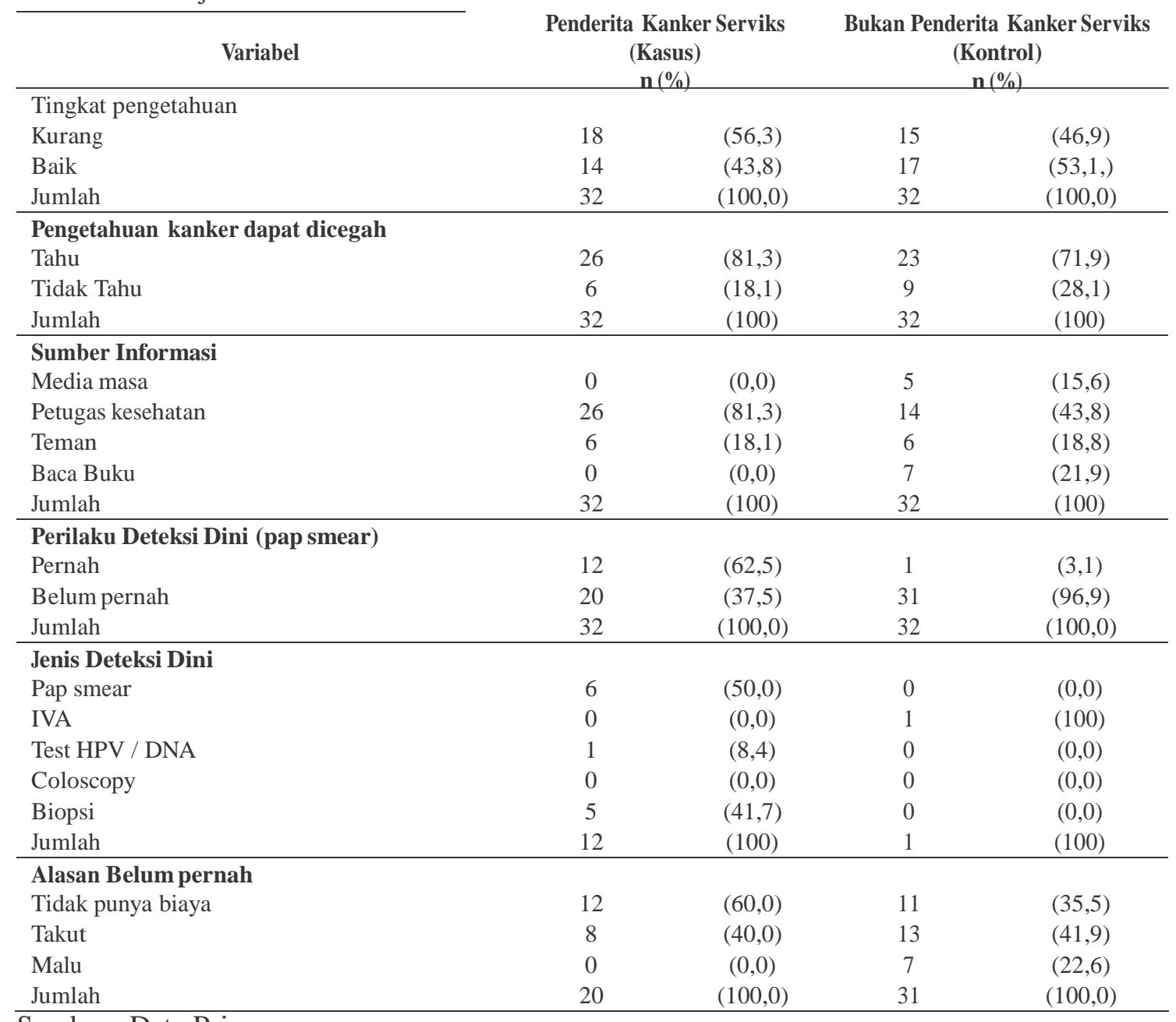


Tabel 3. Gambaran tentang perilaku mencegah kanker serviks dengan vaksinasi HPV pada kasus dan kontrol di RSUD Sukoharjo

\begin{tabular}{|c|c|c|c|c|}
\hline \multirow{2}{*}{ Dapat Info cara mencegah } & \multicolumn{2}{|c|}{$\begin{array}{c}\text { Penderita Kanker Serviks } \\
\text { (Kasus) } \\
\mathbf{n}(\%) \\
\end{array}$} & \multicolumn{2}{|c|}{$\begin{array}{c}\text { Bukan Penderita Kanker Serviks } \\
\text { (Kontrol) } \\
\text { n(\%) }\end{array}$} \\
\hline & & & & \\
\hline Pernah & 24 & $(75,0)$ & 22 & $(68,7)$ \\
\hline Tidak Pernah & 8 & $(25,0)$ & 10 & $(31,3)$ \\
\hline Jumlah & 32 & $(100,0)$ & 32 & $(100,0)$ \\
\hline \multicolumn{5}{|l|}{ Tawaran Vaksinasi HPV } \\
\hline Pernah & 15 & $(46,9)$ & 4 & $(25,0)$ \\
\hline Belum Pernah & 17 & $(53,1)$ & 24 & $(75,0)$ \\
\hline Jumlah & 32 & $(100,0)$ & 32 & $(100,0)$ \\
\hline \multicolumn{5}{|l|}{ Pernah vaksinasi HPV } \\
\hline Pernah & 0 & $(0,0)$ & 4 & $(25,0)$ \\
\hline Belum Pernah & 32 & $(100,0)$ & 24 & $(75,0)$ \\
\hline Jumlah & 32 & $(100,0)$ & 32 & $(100,0)$ \\
\hline \multicolumn{5}{|l|}{ Tempat melakukan vaksinasi } \\
\hline RS & 0 & $(0)$ & 4 & $(100)$ \\
\hline Klinik Dokter spesialis & 0 & $(0)$ & 0 & $(0)$ \\
\hline Jumlah & 0 & $(0)$ & 4 & $(100)$ \\
\hline \multicolumn{5}{|l|}{ Alasan belum pernah Vaksinasi } \\
\hline Tidak tahu & 12 & $(37,5)$ & 20 & $(83,3)$ \\
\hline Biaya mahal & 20 & $(62,5)$ & 4 & $(16,7)$ \\
\hline Jumlah & 32 & $(100,0)$ & 24 & $(100,0)$ \\
\hline
\end{tabular}

Sumber : Data Primer

Karakteristik penderita kanker serviks (kasus) dan kelompok kontrol berdasarkan tingkat pendidikan di RSUD Sukoharjo hampir tidak ada perbedaan. Kurang dari separuh tingkat pendidikan pada kelompok kelompok adalah lulusan Sekolah Dasar, yaitu 22 orang $(68,8 \%)$ pada kasus dan 20 orang $(62,5 \%)$ pada kontrol. Berdasarkan jenis pekerjaan, pada kelompok kasus penderita kanker serviks maupun kontrol di RSUD Sukoharjo paling banyak adalah Ibu rumah tangga. Namun pada kelompok kasus IRT sedikit lebih rendah dari pada kelompok kontrol. Jenis pekerjaan paling sedikit pada kasus dan kontrol adalah pegawai. Untuk lebih jelasnya karekteristik tingkat pendidikan dan pekerjaan dapat dilihat pada tabel 1 .

Pada tabel 2 dan 3 ditampilkan gambaran tentang tingkat pengetahuan, perilaku deteksi dini kanker serviks dan melakukan vaksinasi HPV pada kelompok kasus dan kontrol di RSUD Sukoharjo. Hasil penelitian menunjukkan, pada kasus penderita kanker di RSUD Sukoharjo, tingkat pengetahuan tentang kanker serviks sedikit lebih banyak yang memiliki tingkat pengetahuan kurang yaitu 18 orang $(56,3 \%)$ daripada kelompok bukan penderita yaitu 15 orang $(46,9 \%)$. Namun demikian secara garis besar, proporsi tingkat pengetahuan antara kelompok kasus dan kontrol hampir seimbang. Sebagian besar responden juga sudah tahu bahwa kanker serviks dapat dicegah. Informasi tentang pencegahan kanker serviks pada kelompok kasus sebagain besar diperoleh dari petugas kesehatan $(81,3 \%)$, sedangkan pada kelompok kontrol hampir separuh dari petugas kesehatan $(43,8 \%)$ dan ada sebagian pada kelompok kontrol mendapatkan informasi bahwa penyakit kanker serviks bisa dicegah dari baca buku $(21,9 \%)$, teman $(18,8 \%)$, dan media masa $(15,6 \%)$.

Pada variabel deteksi dini, antara kasus penderita kanker serviks dan bukan penderita menunjukkan hasil proporsi yang berbeda. Pada kelompok kasus pendarita kanker serviks yang belum pernah melakukan deteksi dini ternyata lebih sedikit daripada kelompok kontrol, yaitu 20 orang $(62,5 \%)$ pada kasus dan 31 orang $(95,9 \%)$ pada kontrol. Responden yang pernah melakukan deteksi dini kanker serviks memang cenderung lebih banyak pada kasus penderita kanker serviks yaitu 12 orang $(37,5 \%)$, sedangkan pada kontrol hanya 1 orang $(3,1 \%)$ yang pernah melakukan deteksi dini.

Hasil analisis hubungan antara tingkat pengetahuan dengan kejadian kanker serviks berdasarkan uji chi square diperoleh nilai $\mathrm{p}$ 
Tabel 4. Hubungan Tingkat pengetahuan, Perilaku Deteksi Dini dan Vaksinasi HPV dengan Kejadian kanker Serviks di RSUD Sukoharjo 2013

\begin{tabular}{|c|c|c|c|c|c|c|c|}
\hline Tingkat Pengetahuan & \multicolumn{2}{|c|}{$\begin{array}{c}\text { Penderita Kanker } \\
\text { Serviks (Kasus) } \\
\text { n }(\%)\end{array}$} & \multicolumn{2}{|c|}{$\begin{array}{c}\text { Bukan Penderita } \\
\text { Kanker Serviks } \\
\text { (Kontrol) } \\
n(\%)\end{array}$} & \multicolumn{2}{|c|}{ Jumlah } & p value* \\
\hline Kurang & 18 & $(56,3)$ & 15 & $(46,9)$ & 33 & $(51,6)$ & 0,617 \\
\hline Baik & 14 & $(43,8)$ & 17 & $(53,1)$, & 31 & $(48,4)$ & \\
\hline Jumlah & 32 & $(100,0)$ & 32 & $(100,0)$ & 64 & $(100,0)$ & \\
\hline \multicolumn{8}{|l|}{ Deteksi Dini } \\
\hline Belum penah & 20 & $(62,5)$ & 31 & $(96,9)$ & 51 & $(79,7)$ & 0,002 \\
\hline Pernah & 12 & $(37,5)$ & 1 & $(3,1)$ & 13 & $(20,3)$ & \\
\hline Jumlah & 32 & $(100,0)$ & 32 & $(100,0)$ & 64 & $(100,0)$ & \\
\hline \multicolumn{8}{|l|}{ Vaksinasi HPV } \\
\hline Belum penah & 32 & $(100,0)$ & 28 & $(87,5)$ & 60 & $(93,8)$ & 0,113 \\
\hline Pernah & 0 & $(0,0)$ & 4 & $(12,5)$ & 4 & $(6,2)$ & \\
\hline Jumlah & 32 & $(100,0)$ & 32 & $(100,0)$ & 64 & $(100,0)$ & \\
\hline
\end{tabular}

Sumber : Data Primer

sebesar 0,617 sehingga Ho diterima dan dapat disimpulkan bahwa tidak ada hubungan antara tingkat pengetahuan dengan kejadian kanker serviks di RSUD Sukoharjo. Selanjutnya hasil analisis estimasi faktor risiko diperoleh nilai $\mathrm{OR}=1,457$ dengan 95\% CI : 0,544-3,901.

Analisis hubungan yang dilakukan dengan uji chi square diperoleh nilai $\mathrm{p}$ sebesar 0,002 sehingga Ho ditolak dan dapat disimpulkan bahwa ada hubungan antara perilaku deteksi dini dengan kejadian kanker serviks di RSUD Sukoharjo. Selanjutnya hasil analisis estimasi faktor risiko diperoleh nilai $\mathrm{OR}=18,6$ dengan $95 \% \mathrm{CI}:$ 2,241-154,34. Sehingga disimpulkan bahwa wanita yang belum pernah melakukan deteksi dini kanker serviks mempunyai risiko menderita kanker serviks sebesar 18,6 kali dibandingkan dengan yang pernah melakukan deteksi dini kanker serviks.

Hasil penelitian untuk variabel vaksinasi HPV, menunjukkan bahwa semua responden kasus penderita kanker serviks (100\%) menyatakan tidak pernah melakukan vaksinasi HPV untuk mencegah kanker serviks. Demikian pula pada kelompok kontrol, sebagian besar juga menyatakan belum pernah melakukan vaksinasi HPV yaitu 28 orang $(87,5 \%)$. Hasil analisis hubungan yang dilakukan dengan uji fisher exact diperoleh nilai p sebesar 0,113 sehingga Ho diterima dan dapat disimpulkan bahwa tidak ada hubungan antara perilaku vaksinasi HPV dengan kejadian kanker serviks di RSUD Sukoharjo. Selanjutnya hasil analisis estimasi faktor risiko diperoleh nilai $\mathrm{OR}=2,143$ dengan $95 \% \mathrm{CI}=1,635-2,808$. Dengan demikian meskipun tidak menunjukkan hubungan yang secara statistik signifikan, namun kondisi belum pernah melakukan vaksinasi HPV dapat berisiko terkena kanker serviks.

Secara singkat hasil analisis hubungan antara pengetahuan, perilaku deteksi dini dan vaksinasi HPV dengan kejadian kanker serviks ditampilkan pada tabel sebagai 4 .

Hasil penelitian menunjukkan tidak ada hubungan antara tingkat pengetahuan dengan kejadian kanker serviks di RSUD Sukoharjo $(\mathrm{p}=0,671)$. Pengetahuan sebenarnya merupakan dasar untuk bertindak atau berperilaku benar atau salah dalam mencegah atau mengatasi suatu penyakit. Dengan pengetahuan yang baik, seseorang akan mempunyai sikap yang positif terhadap suatu hal dan akan menentukan tindakan yang perlu dilakukan termasuk upaya untuk berperilaku menghindari hal-hal yang merugikan kesehatan. Seseorang yang memiliki pengetahuan dan pemahaman yang benar tentang kanker serviks, akan melakukan upaya untuk mencegahnya dengan menghindari faktor risiko atau kondisi yang mendukung terjadinya kanker serviks, seperti mengetahui tanda dan gejala kanker serviks, mengetahui cara melakukan deteksi dini, menghindari perilaku merokok atau terpapar rokok, tidak memilih kontrasepsi oral (pil) dalam mengendalian kelahiran, melakukan deteksi dini, melakukan vaksinasi HPV. Sesungguhnya pada penelitian ini, hanya sebagian dari 
responden pada kasus $(43,8 \%)$ dan kontrol $(53,1 \%)$ yang memiliki pengetahuan dengan kategori baik tentang kanker serviks. Sebagian besar $(81,3 \%)$ responden tahu bahwa kanker serviks dapat dicegah, dimana informasi tersebut sebagian besar diperoleh dari petugas kesehatan $(81,3 \%)$. Hasil penelitian ini sejalan dengan penelitian Kusmastuti dan Ambarwati (2010), tingkat pengetahuan masyarakat di wilayah Kabupaten Sukoharjo tentang pemeriksaan pap smear banyak dalam kategori sedang dibandingkan dengan perawat di RSUD Sukoharjo memiliki pengetahuan dengan kategori baik yang disebabkan karena tingkat pendidikan dan profesinya. Namun demikian, dalam hal hubungan pengetahuan dengan kejadian kanker serviks, penelitian ini tidak sejalan dengan penelitian Apriyanti (2014), yang menyimpulkan ada hubungan antara tingkat pengetahuan wanita usia subur tentang pap smear dengan kejadian kanker serviks. Demikian pula dengan hasil penelitian Mustikawati (2009), yang menunjukkan bahwa adanya hubungan yang kuat dan positif antara pengetahuan tentang kanker serviks dengan perilaku pencegahan kanker serviks pada WTS di Panti Sosial "Harapan Mulya" Jakarta Barat $(r=0,767)$. Pengetahuan yang baik dapat membentuk perilaku pencegahan kanker serviks, sehingga mengurangi risiko kejadian kanker serviks.

Upaya pencegahan primer terhadap terjadinya kanker dapat dilakukan dengan memberikan promosi kesehatan tentang kanker serviks dan deteksi dini yang berupa pap smear. Upaya promotif utama adalah meningkatkan pengetahuan atau pemahaman masyarakat dengan cara memberikan pendidikan seks mulai remaja dalam rangka mengurangi faktor risiko sehingga dapat mencegah kemungkinan infeksi virus HPV, menunda hubungan seks remaja atau pendidikan seks yang bersih, mengembangkan vaksin HPV dan mengobati infeksi vaginal sehingga $\mathrm{pH}$ tetap dapat dipertahankan. Peningkatan pengetahuan akan memberikan sikap baik terhadap upaya pencegahan. Sesuai penelitian Mulyati (2015), terdapat pengaruh positif pendidikan kesehatan melalui film dengan sikap ibu pada deteksi dini kanker serviks. Upaya preventif utama yaitu: mengembangkan obat antivirus yang efektif, meningkatkan skrining terhadap kemungkinan karsinoma serviks, meningkatkan pendidikan dan melakukan skrining masyarakat yang dianggap menjadi sumber kemungkinanan karsinoma serviks uteri.

Menurut Sukamto (2002), pengetahuan merupakan domain yang sangat penting untuk terbentuknya perilaku terbuka (over behavior) perilaku yang didasari pengetahuan bersifat langgeng. Pengetahuan juga diperngaruhi oleh faktor antara lain: tingkat pendidikan; Informasi, budaya, pengalaman, sosial ekonomi. Pada penelitian ini, tingkat pendidikan responden baik ada kasus maupun kontrol sama-sama masih dalam kategori rendah karena sebagian besar hanya lulusan $\mathrm{SD}$, informasi yang diperoleh masih sangat tergantung dari petugas kesehatan, sehingga di sini peran petugas kesehatan dalam memberikan informasi dengan tepat sangat diharapkan, terutama informasi bahwa kanker serviks bisa diketahui atau dideteksi sejak dini dan dapat dicegah dengan vaksinasi.

Penelitian dilakukan di RSUD Sukoharjo, dimana hampir semua pasien yang datang dan dilayani adalah masyarakat pedesaan dengan kondisi masyarakat termasuk sosial ekonomi rendah, karena sebagian besar hanya sebagai Ibu Rumah Tangga (IRT), sehingga benar bahwa lebih dari separuh $(62,5 \%)$ penderita kanker serviks dan sebagian besar $(95,9 \%)$ bukan penderita kanker serviks belum pernah melakukan deteksi dini (pap smear). Hasil uji chi square menyimpulkan ada hubungan antara perilaku deteksi dini dengan kejadian kanker serviks $(\mathrm{p}=0,002)$. Hal ini sesuai dengan penelitian yang telah dilakukan oleh Afriatin (2012), yang menyimpulkan ada hubungan antara deteksi dini papsmear dengan kejadian kanker serviks pada PUS usia 2035 tahun di Poli Onkologi RSUD Dr.Soegiri Lamongan. Afriatin dan Ekawati menyatakan bahwa responden yang mengikuti pap smear seluruhnya tidak terkena kanker serviks.

Otto (2005), menyatakan cara terbaik yang dapat dilakukan untuk mencegah kanker serviks adalah dengan screening gynaecological dan apabila dibutuhkan dapat dilengkapi dengan treatment yang terkait dengan kondisi pra kanker agar tidak berkembang menjadi kanker dan masih dapat diselamatkan dari 
risiko kematian. Rekomendasi ACS (American Cancer Society) sebagai sarana penapisan bagi wanita menyarankan pemeriksaan pap smear (papaniculou smear) sebagai cara mencegah timbulnya kanker serviks. .

Namun dalam penelitian ini, reponden masih banyak yang belum melakukan deteksi dini, walaupun informasi dan tawaran sudah diperoleh. Alasan yang diungkapkan oleh responden dalam hal belum pernah deteksi dini adalah lebih dari separuh (60\%) pada kasus menyatakan karena tidak punya biaya, sedangkan pada kontrol lebih dari sepertiga $(35,5 \%)$ juga karena tidak punya biaya dan hampir separuhnya (40\%) menyatakan alasan karena takut. Hal tersebut terkait dengan pengetahuan yang kurang dari responden tentang kanker serviks. Sebenarnya pengetahuan responden yang cukup mempengaruhi pengetahuan tentang deteksi dini pencegahan kanker serviks dengan cara pap smear.

Setiap wanita yang berumur 18 tahun, atau wanita yang telah aktif secara seksual selayaknya mulai melakukan pemeriksakan pap smear. Pemeriksaan ini sebaiknya dilakukan setiap tahun walaupun tidak ada gejala kanker. Pemeriksaan dilakukan sering pada wanita yang mempunyai lebih dari satu pasangan, telah berhubungan seksual sejak remaja, mempunyai penyakit kelamin, merokok, dan adanya infeksi HPV(Bustan, 2007).

Hasil penelitian terkait dengan perilaku pencegahan kanker serviks, sebagian besar responden baik pada penderita dan bukan penderita kanker serviks telah mendapatkan informasi bahwa kanker serviks bisa dicegah. Selanjutnya bahwa dalam rangka mencegah kanker serviks dapat dilakukan dengan melakukan vaksinasi HPV. Pada kelompok penderita kanker serviks, menyatakan sebagian pernah mendapatkan tawaran vaksinasi dan sebagian lagi belum pernah, sedangkan pada kelompok bukan penderita kanker serviks (kontrol) sebagian besar belum pernah mendapatkan tawaran vaksinasi HPV. Meskipun sudah mendapatkan tawaran untuk melakukan vaksinasi HPV, namun demikian perilaku atau tindakan dalam melakukan vaksinasi HPV, seluruh (100\%) responden penderita kanker serviks belum pernah melakukan vaksinasi dan sebagian besar $(75 \%)$ bukan penderita juga belum pernah melakukan vaksinasi HPV.

Menurut Wulandari (2010) pada pertengahan tahun 2006 telah beredar vaksin untuk mencegah infeksi HPV tipe 16 dan 18 yang menjadi penyebab kanker serviks. Vaksin ini bekerja dengan cara meningkatkan kekebalan tubuh dan menangkap virus HPV sebelum memasuki sel-sel serviks. Vaksinasi HPV ini efektif diberikan pada perempuan usia produktif. Selain membentengi dari penyakit kanker serviks, vaksin ini juga bekerja ganda yaitu melindungi perempuan dari ancaman HPV tipe 6 dan 11 yang menyebabkan kutil kelamin. Menurut Radji (2009), terdapat dua jenis vaksin kanker yaitu vaksin kanker propilaktik yang digunakan untuk mencegah terjadinya kanker dan terapetik yang digunakan untuk mengobati penyakit kanker dan meningkatkan daya tahan tubuh terhadap kanker. Vaksin kanker yang telah disetujui penggunaannya oleh FDA Amerika Serikat adalah vaksin propilaktik untuk mencegah timbulnya penyakit kanker serviks yang disebabkan oleh Human Papilloma Virus (HPV).

Pada penelitian ini, belum terbukti bahwa vaksinasi HPV dapat menjadi faktor pencegah kejadian kanker serviks, hal ini dikarenakan data hasil penelitian baik pada penderita kanker serviks (kasus) dan bukan penderita (kontrol) menunjukkan tidak ada perbedaan proporsi yang telah melakukan vaksinasi HPV. Pada kedua kelompok penelitian masih banyak yang belum melakukan vaksinasi HPV. Adapun alasan yang disampaikan oleh responden mengapa belum melakukan vaksinasi HPV adalah tidak tahu dimana melakukan vaksinasi $(37,5 \%)$ dan karena alasan biaya mahal $(62,5 \%)$.

Hal ini sesuai dengan penelitian yang dilakukan oleh Christy (2012), yang melakukan penelitian pada siswa SMU menyimpulkan bahwa siswi takut apabila vaksinasi HPV tidak aman, takut efek samping dari vaksinasi, dan merasa belum siap divaksinasi karena masih perlu informasi yang lebih banyak mengenai vaksinasi. Terkait dengan masalah biaya, hasil penelitian Kwan (2008), menyatakan bahwa Biaya merupakan isu yang cukup penting dalam memutuskan tindakan vaksinasi 
HPV pada remaja. Demikian pula pada penelitian ini, sebagian besar responden belum melakukan vaksinasi karena alasan faktor biaya. Hal ini sesuai dengan penelitian Christy (2012), bahwa penolakan terhadap vaksinasi HPV kebanyakan terjadi karena diperlukan biaya tinggi. Tidak adanya hubungan antara vaksinasi HPV dengan kejadian kanker serviks disebabkan karena baik pada kasus penderita kanker serviks dan kontrol menunjukkan proporsi yang sama, sebagian besar belum pernah melakukan vaksinasi HPV. Hal yang penting juga, pada penelitian Alexander (2012), menyimpulkan tentang keputusan melakukan vaksinasi HPV bahwa orang tua dan anakanak memainkan peran aktif dalam proses pengambilan keputusan melakukan vaksinasi HPV, dimana peran individu dipengaruhi oleh banyak faktor, yang merekomendasikan vaksin HPV, dan penerimaan intervensi vaksin pada masa yang akan datang.

\section{Penutup}

Berdasarkan hasil penelitian dapat disimpulkan bahwa ada hubungan antara upaya deteksi dini dengan kejadian kanker serviks, tidak ada hubungan antara pengetahuan dan pemberian vaksinasi HPV dengan kejadian kanker serviks. Pengetahuan yang baik tidak terbukti sebagai faktor pencegah kanker serviks. Upaya deteksi dini yang belum pernah dilakukan merupakan faktor fisiko terjadinya kanker serviks. Pemberian vaksin HPV merupakan faktor pencegah kanker serviks meskipun pada penelitiaan ini belum terbukti secara signifikan.Sebanyak $50 \%$ dari penderita kanker serviks mencari pengobatan alternative, sebelum menjalani operasi dan pengobatan di RSUD Sukoharjo, yaitu ke pengobatan tradisional China.

\section{Daftar Pustaka}

Apriyanti, A. 2014, Hubungan Pengetahuan Wanita Usia Subur Tentang Pap Smear Dengan Kejadian Kankser Serviks di Puskesmas Tasikmadu Karanganyar, Jurnal Maternal 10.

Afriatin, N dan Ekawati, H, 2013, Hubungan Deteksi Dini Pap Smear dengan Kejadian Kanker Serviks pada Pasangan Usias Subur Usia 2035 Tahun di Poli Onkologi RSUD Dr. Soegiri Lamongan.Jurnal Surya 3 (12).

Alexander, AB, et al. 2012. Parent-son Decision- making about Human Papillomavirus Vaccination: a Qualitative Analysis, Biomed Central Pediatric, 12:192.

Bustan, M.N. 2007. Epidemiologi Penyakit Tidak Menular. Jakarta: Rineka Cipta.

Christy, A dan Putra, A.E. 2012, Penerimaan Vaksinasi Kanker Serviks Pada Siswi SMADi Kabupaten Badung Tahun 2012, Journal Community Health 1 (2).

Dinkes Jawa Tengah. 2008. Profil Kesehatan Dinas Provinsi Jawa Tengah Tahun 2008. Semarang : Dinkes Jawa Tengah.

Dinkes Sukoharjo. 2012. Data penyakit Tidak Menular di Kabupaten Sukoharjo. Sukoharjo: DKK Sukoharjo.

Has, D.F dan Hendrati, LY. 2009. Faktor Risiko Karakteristik dan Perilaku Seksual Terhadap Kejadian Kanker Serviks. The Indonesia Journal of Public Health 6 (1).

Indrawati, Tatik dan Heni Fitriyani. 2012. Hubungan Personal Hygiene Organ Genital dengan Kejadian Kanker Serviks di RSUP Dr. Kariyadi Kota Semarang. Dinamika Kebidanan 2 (1).

Kusmatuti, N dan Ambarwati, WN, 2001, Perbedaan Tingkat Pengetahuan dan Partisipasi Pap Smear antara Perawat dengan Masyarakat di Kabupaten Sukoharjo.

Kartikawati, Ei 2013. Awas!!! Bahaya Kanker payudara \& kanker Serviks. Bandung : Buku Baru.

Kwan, T., et al. 2008. Barriers and Facilitators to Human Papillomavirus Vaccination among Chinese Adolescent Girls in HongKong: A Qualitative-Quantitative Study. Sexually Transmitted Infections, 84(3), 227-232.

Mulyati, S., Suwarsa, O dan AryaI FD,. 2015. Pengaruh Media Film tehadap sikap reposden pada deteksi Dini serviks. Jurnal Kesmas Universitas Negeri Semarang, No. 11(1), Tahun 2015

Mustikawati, IS. 2009, Pengetahuan Wanita Tuna Susila (WTS) Tentang Kanker Servis dan Perilaku Pencegahan Kanker di Panti Sosial "Harapan Mulya" Jakarta Barat 2009, Forum Jurnal Ilmiah 2 (2).

Otto, S.E, 2005. Buku Saku Keperawatan Onkologi. Jakarta: EGC

Pratiwi, Muthiah Rissa. 2009. Pengaruh pemakaian alat kontrasepsi kombinasi progesteron estrogen terhadap kejadian kanker leher rahim di RSUD DR. Moewardi Surakarta. Surakarta.

Radji, M, 2009, Vaksi Kanker . Majalah Ilmu Kefarmasian Vol. VI No. 3 Desember 2009

Rasjidi, I. 2009. Epidemiologi Kanker Sekviks. 
Indonesian Journal of Cancer 3 (3).

RSUD Sukoharjo. 2013. Buku Register Pasien Bangsal VK. Sukoharjo: RSUD Sukoharjo.

Sastrosudarmono, Wh. 2011. Kanker The Silent Killer. Jakarta: Garda Media.

Suhartini, dan Tutiek Herlina. Hubungan Antara Usia Menikah dan Paritas dengan Kejadian Kanker Serviks di RSUD Dr. Soeroto Ngawi. Jurnal Penelitian Kesehatan Suara Forikes 1 (1).

Sukamto, S. 2007. Sosiologi Suatu Pengantar, Jakarta : Raja Grafindo Sejahtera

Wijaya, Delia. 2010. Pembunuh Ganas Itu Bernama
Kanker Serviks. Sinar Kejora: Yogyakarta.

World Health Organization (WHO). 2013. Bulletin of The World Health Organization 2012; 90 : 478-478A.

Wulandari, A.S. 2010. Pengertian Dan Pemahaman Resiko Ca Cervix Pada Wanita Usia Subur Di Indonesia. Universitas Wijaya Kusuma. Surabaya.

Yayasan Kanker Indonesia (YKI). 2011. www. yayasan kanker indonesia.com.

Yayasan Peduli Kanker Serviks Indonesia (YPKSI). 2011. www.yayasan peduli kanker serviks indonesia. 